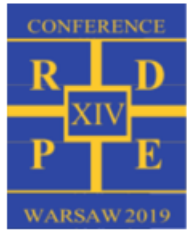

\title{
Characteristics of agro and wood biomass combustion in the stream of inert material
}

\author{
Konrad Kaczyński ${ }^{1,},{ }^{*}$ Katarzyna Kaczyńska ${ }^{1}$, and Piotr Pełka ${ }^{1}$ \\ ${ }^{1}$ Czestochowa U niversity of Technology, Faculty of M echanical Engineering and Computer Science, Institute of Thermal M achinery, \\ al. A rmii Krajowej 21, 42-201 Czestochowa, kkaczynski@imc.pcz.pl, Poland
}

\begin{abstract}
A gricultural residual biomass presents a high potential for energy use around the world, often not utilized to a large extent due to its significant differences with respect to other biomass types, such as the one of wood origin. These differences are mainly related to the characteristics of its ashes (quantity and composition) which increase certain problematic phenomena during combustion, among them ash sintering. The main purpose of this article is the experimental study of these issues for various agro pellets and wood pellets, analyzed in various operating conditions in a laboratory reactor with a circulating bed.
\end{abstract}

\section{Introduction}

In view of the world's population continues to grow at a high rate, such that today's population is twice that of 1960 , and is projected to increase further to 9 billion by 2050 [1] increased energy demand is inevitable. In the year 2018, the world's primary energy consumption increased al most twice as fast as the average rate recorded since 2010 and is approx. to 14.3 billion tons of oil equival ent which is about $599 \mathrm{EJ}$ (exajoules), along with an average growth rate of $2.3 \%$ per year [2]. The production of energy by burning solid fuels as the main item in energy mixes is prevalent across many countries in the world, including the largest energy producers, such as the USA, China, India and most of the European Union (EU) countries. It seems that coal fuels will remain an important element of their economies for at least several dozen years [3]. However, a key policy solution to mitigate climate change is to increase renewable energy production [4]. The renewable energy market is expected to grow dynamically in the near future, and play a significant role in the world(6) future energy mix. The Paris agreement-2015 is the first agreement in the world to bind the treaty to reduce climate change [5]. The sustainable development goals of the $U$ nited $N$ ations also underline the importance of energy. 'Affordable and clean energy' in Goal 7 and 'Climate action' in Goal 13, highlight the significance of new and renewable energy to transform the world [6]. In 2018, renewable energy accounted for around $26 \%$ of global electricity production. Hydropower remains the largest renewable source, satisfying $16 \%$ of global electricity demand, followed by wind $(5 \%)$, solar farm $(2 \%)$ and bioenergy (3\%) [2]. Due to the wide availability of biomass around the world, it is a renewable energy source with high growth potential [7]. Biomass is referred to as a carbon neutral fuel because there is no net addition of carbon dioxide in the atmosphere unlike fossil fuels [8]. Biomass can be transformed into solid, liquid and gaseous form using modern technologies, and thus becomes an efficient and clean energy supplier for all sectors such as heat, power and transport fuel [9]. There are two routes for biomass conversion, namely the biochemical route and the thermochemical route. The biochemical conversion process uses enzymes, bacteria or other microorganisms to convert lignocellulosic biomass into liquid biofuels. In the thermochemical conversion process, biomass converts to any form of energy in the presence of heat and with a controlled supply of oxygen. In comparison to the biochemical route, the thermochemical route has certain advantages, such as the utilization of entire biomass, faster kinetics, and flexibility in the feedstock [10]. There are three main thermochemical pathways, such as direct combustion [11,12], gasification [13], and pyrolysis [14]. Until now, mainly biomass from forest origin (residue after logging and wood processing up to $27 \%$ of wood mass) was used for energy purposes $[4,15]$. However, along with the growing demand, the non-wood biomass market developed - originating, among others, from agricultural crops, energy plantations. In the energy sector, processed biomass is most commonly used, in the form of woodchips, sawdust, pellets and briquettes. The advantage of using biomass as fuel is the possibility of rapid technological adaptation of coal installations. It is very beneficial to use fluidized bed combustion technology due to the possibility of reducing emissions of environmental pollutants arising during combustion and the possibility of combusting inferior fuels, e.g. biomass. In the case of wood biomass, comprehensive knowledge on thermal energy conversion has long been accumulated and a number of studies have been published [16-22], however, in the case of agricultural biomass as well as energy plantations, more research and analysis is still needed due to the fact that thermal the conversion of these fuels is significantly different from the conversion of wood biomass. A lot of studies concerned the combustion of pellets in grate boilers. At work [23] NOx emission behavior of three pelletized energy crops was assessed. 
The experiment found that the ash content and chemical composition of fuels had a significant impact on the need for combustion air. During the experiment [24] various fuels obtained from new energy crops - herbaceous plant, poplar and manioc - were burned. Particular emphasis was placed on explaining the role of the main elements forming ash, sediments and emissions of solid particles (fractions of fine and coarse ash particles) based on experimental data. The main purpose of the work [25] was to assess the suitability of multi-fuel combustion technology of various pelletized energy plants in terms of the required adaptations of four combustion parameters, i.e. the ratio of charge, lambda, primary / secondary air distribution and residence time on the grate, leading to the best combustion efficiency in the system. The publication [26] quantifies the release of $\mathrm{K}, \mathrm{Cl}, \mathrm{S}$ and $\mathrm{P}$ for two species of energy plants and their impact on the ash flow phenomenon. However, the issue of agro biomass combustion in a small-scale fluid bed was discussed in a review article [27], where the most important problems concerning biomass combustion were presented, paying special attention to the presence of alkali metal compounds. The mechanisms leading to slagging and contamination of the heating surfaces of boilers have been explained. Experimental research on the biomass of various origins was presented in [28], where the process of combusting spherical "briquettes" (obtained in the process of grinding and pressing) of agro biomass (wheat straw and energetic willow) and wood biomass (Scots pine) in the circulating fluid layer was analyzed at $850^{\circ}$ C. In order to determine the fuel combustion kinetics, a single briquette was introduced into the combustion chamber, which was placed in a specially constructed measuring system. Surface and pellet center temperatures were measured with thermocouples. Simultaneously with the measurement of the sample temperature, ignition time, volatile component burning time and total pellet burning time were measured. However, for the analysis of pollutant emissions, briquettes were burned directly in a fluidized layer at $850^{\circ} \mathrm{C}$. Emissions of pollutants (NO, $\mathrm{N}_{2} \mathrm{O}, \mathrm{NO}_{2}, \mathrm{SO}_{2}, \mathrm{CO}, \mathrm{HCl}, \mathrm{HF}$ and $\mathrm{HCN}$ ) were measured and oxygen concentration measurements were made. However, to characterize such a versatile fuel as biomass, further experimental research is necessary. There are few analyzes in the literature regarding the combustion of a single biomass particle. In contrast to research [28], the experiment described in this paper was conducted using processed biomass fuels specially dedicated to combustion in the power industry.

\section{Biomass as fuel}

The components of biomass include cellulose, hemicelluloses, lignin, lipids, proteins, simple sugars, starches, water, hydrocarbon, ash, and other compounds. The concentration of each class of compound varies depending on species, type of plant tissue, stage of growth, and growing conditions. [29]. The bulk composition of biomass in terms of carbon, hydrogen, and oxygen $(\mathrm{CHO})$ does not differ much among different biomass sources. Typical (dry) weight percentages for $\mathrm{C}$, $\mathrm{H}$, and $\mathrm{O}$ are 30 to $60 \%, 5$ to $6 \%$, and 30 to $45 \%$ respectively. [30].

\subsection{Effects of certain elements of fuel}

Certain elements in biomass deserve special attention. These include chlorine, potassium, sulfur, nitrogen, and silicon. Perhaps the most important element, with regard to its behavior in different combustion related problems is chlorine. Chlorine, which is found in high quantities in certain biomass types, such as straw, may affect operation by corrosion. The high chlorine and al kali content of some biomass fuels can cause severe damage to the combustion units. Chlorine concentration often dictates the amount of alkali (potassium) vaporized during combustion as strongly as it dictates the transport of alkali from the fuel to surfaces, where the alkali often forms sulfates. In the absence of chlorine, al kali hydroxides are the major stable gas phase species in moist, oxidizing environments i.e., combustion gases [29]. High percentages of silicon together with potassium and chlorine also play their role in causing severe ash deposition problems at high or moderate combustion temperatures. Potassium is the dominant alkali source in most biomass fuels $[29,31,32]$. Biomass is usually low in sulfur. The high percentages of these elements $(\mathrm{Cl}, \mathrm{K}, \mathrm{Si})$ also pose grave concerns for bed agglomeration problems in fluidized bed boilers.

\subsection{Ash}

The major inherent ash forming elements in biomass include $\mathrm{Si}, \mathrm{Al}, \mathrm{Ti}, \mathrm{Fe}, \mathrm{Ca}, \mathrm{Mg}, \mathrm{Na}, \mathrm{K}, \mathrm{S}$, and $\mathrm{P}$. Table $\mathrm{I}$ shows the ash analysis of some selected biofuels and bituminous coal [27]. High alkali (potassium) and $\mathrm{Si}$ content typically gives low ash melting temperatures while $\mathrm{Mg}$ and $\mathrm{Ca}$ increase ash melting temperature $[27,31]$. Although a major fraction of low melting point al kali is rel eased into the gas phase, the part left in the ash may deliver detrimental effects (bed agglomeration) during fluidized bed combustion. Ash sintering, softening, and melting temperatures can differ significantly among biofuels, and this characteristic is essential in determining temperature control to avoid sintering or slagging (resulting in deposits on, e.g., boiler tubes).

\section{Motivations}

The aim of the experimental research was:

- analysis of the combustion process of selected biomass fuels dedicated to combustion in technology with CFB,

- comparison of the agro and wood biomass combusting process,

- comparison of the combustion mechanism of selected pellets in clean air and the conditions of the circulating fluidized bed,

- detailed analysis of the mass loss of pellets combusted at variable fluidized bed temperatures. 
Table 1. A sh analysis of some biofuels and bituminous coal (mass basis \% ash) [27].

\begin{tabular}{|c|c|c|c|c|c|c|c|c|c|c|c|}
\hline Fuel & $\mathbf{S i O}_{2}$ & $\mathbf{A l}_{\mathbf{2}} \mathbf{O}_{3}$ & $\mathbf{F e}_{2} \mathbf{O}_{3}$ & $\mathbf{M n}$ & $\mathbf{M g O}$ & $\mathbf{C a O}$ & $\mathbf{N a}_{2} \mathbf{O}$ & $\mathbf{K}_{2} \mathbf{O}$ & $\mathbf{T i O}_{2}$ & $\mathbf{P}_{2} \mathbf{O}_{\mathbf{5}}$ & $\mathbf{S O}_{\mathbf{3}}$ \\
\hline Wood pellets & 4.3 & 1.3 & 1.5 & 5.9 & 8.5 & 55.9 & 0.6 & 16.8 & 0.1 & 3.9 & 1.3 \\
\hline Sunflower pellets & 2.9 & 0.6 & 0.8 & 0.1 & 21.6 & 21.6 & 0.24 & 22.8 & 0.1 & 15.2 & 14.0 \\
\hline Straw & 53.1 & 3.6 & 1.2 & --- & 3.0 & 17.7 & 4.5 & 30.0 & --- & 4.1 & --- \\
\hline Greenhouse residue & 28.4 & 3.9 & 18.4 & 0.3 & 5.7 & 25.8 & 0.8 & 9.7 & 0.8 & 3.8 & $\cdots$ \\
\hline Bituminous Coal & 59.7 & 20.3 & 7.0 & $<0.01$ & 1.9 & 1.8 & 1.0 & 2.3 & 0.9 & 0.1 & 1.3 \\
\hline
\end{tabular}

\section{Experiment}

During experimental research was analyzed the mass loss of biomass pellets. In the research two types of fuels were used: wood and agro-biomass. The research was carried out in three different temperatures of the combustion chamber: $850^{\circ} \mathrm{C}, 750^{\circ} \mathrm{C}$ and $650^{\circ} \mathrm{C}$. The research was performed without inert material and in a stream of inert material: $\mathrm{Gs}=2,5 \mathrm{~kg} / \mathrm{m} 2 \mathrm{~s}$ and $\mathrm{Gs}=5 \mathrm{~kg} / \mathrm{m} 2 \mathrm{~s}$. The values of the stream of inert material are characteristic for the upper and middle areas of the real zone of the fluidized bed boilers. The temperature of $850^{\circ}$ corresponds to the combustion temperature of fuels in professional fluidized bed boilers. The conducted experiments may also prove to be helpful due to the possibility of using biomass in other processes, among others rapid pyrolysis and gasification $[13,14]$.

\subsection{Experimental stand}

The research was carried out on a specially constructed test stand. The experimental stand made it possible to model the conditions of the circulating fluidized bed. the experimental stand is presented in Fig. 1. [33].

\subsection{Research material}

Four types of biomass pellets, each in the shape of a cylinder, were used for the study. Oak sawdust pellets, a mixture of beech and oak sawdust and straw had a diameter of $6 \mathrm{~mm}$, while the diameter of pellets from sunflower husk was $8 \mathrm{~mm}$. The mass of the samples was $0.73 \pm 0.03 \mathrm{~g}$. Table 2 contains the results of the technical analysis of the tested fuels.

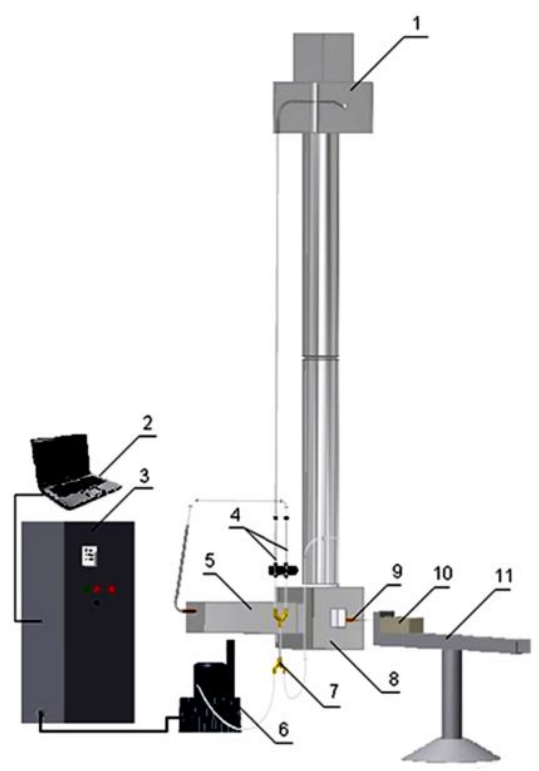

Fig. 1. The layout of the test apparatus. (1) vessel of inert material, (2) computer (3) control panel, (4) rotametres, (5) gas heater, (6) ventilator, (7) T-connector, (8) combustion chamber, (9) fuel particle, (10) tensometric branch scale, (11) support.

Table 2. Results of technical analysis of biomass fuels.

\begin{tabular}{|c|c|c|c|c|c|}
\hline Pellets & Volatile [\%] & Moisture [\%] & Ash [\%] & Fixed coal [\%] & $\begin{array}{c}\text { Combustion } \\
\text { heat [MJ/kg] }\end{array}$ \\
\hline Oak sawdust & 79.6 & 8.7 & 1.2 & 10.5 & 18.2 \\
\hline 30\%beech and 70\%oak sawdust & 77.7 & 8.8 & 1.3 & 10.7 & 17.9 \\
\hline Sunflower husk & 73.8 & 8.4 & 5.5 & 12.3 & 19.8 \\
\hline Straw & 71.8 & 8.7 & 12.2 & 7.3 & 16.2 \\
\hline
\end{tabular}

\section{Results of the experiment}

Fig. 2. presents a comparison of pellets combustion time combusted at different conditions in a circulating fluidized bed. Fig. 3. presents percentage comparison of pellets combustion time during reduction of the combustion chamber temperature compared to the reference temperature $\left(850^{\circ} \mathrm{C}\right)$. As expected, when combusting pellets without inert material, lowering the temperature in the combustion chamber results in longer combusting time for all types of biomass fuels. The results of mass loss of wood biomass pellets (pellets from oak sawdust and pellets from a mixture of beech and oak sawdust) combusted at different temperatures and at Gs = $2.5 \mathrm{~kg} / \mathrm{m}^{2} \mathrm{~s}$ indicate that, as in the case of combustion without inert material, lowering the temperature in the combustion chamber increases the pellets combusting time. It is different in the case of agro biomass combustion, where the combusting time at $850^{\circ} \mathrm{C}$ is the longest. At this temperature the phenomenon of ash softening is manifested by the sticking of sunflower husk pellets through quartz sand. The sand forms a durable surface surrounding the incinerated pellet, consequently preventing the oxidizer from entering the combusted 
pellet. The residue after combusting sunflower husk pellet at $850^{\circ} \mathrm{C}$, tests were carried out in a stream of inert material at $\mathrm{Gs}=2.5 \mathrm{~kg} / \mathrm{m}^{2} \mathrm{~s}$ was shown in Fig. 4. A similar effect was observed when combusting straw pellets at $850^{\circ} \mathrm{C}$. The straw pellets combusted at $850^{\circ} \mathrm{C}$ were sintered. The residue after combusting straw pellet at 850 ${ }^{\circ} \mathrm{C}$, tests were carried out in a stream of inert material at Gs $=2,5 \mathrm{~kg} / \mathrm{m}^{2} \mathrm{~s}$ was shown in Fig. 5 . Analyzing the combusting of pellets at an increased value of the inert material stream Gs $=5 \mathrm{~kg} / \mathrm{m}^{2} \mathrm{~s}$, in the case of wood biomass it can again be seen that lowering the temperature in the combustion chamber results in longer combusting time. In the case of agro biomass combustion, as in the case of combustion in Gs $=2.5 \mathrm{~kg} / \mathrm{m}^{2} \mathrm{~s}$, during the combusting of pellets from sunflower husk, the formation of a coating was observed, which was partially broken down as a result of the mechanical impact of inert material - Fig. 6. On the other hand, the sinter was formed during combustion of straw was completely broken down. The longest combusting time of agro biomass was recorded at $750{ }^{\circ} \mathrm{C}$, and the shortest at $650{ }^{\circ} \mathrm{C}$. Which is due to the increased erosive effects of the inert material on the pellet surface at a lower temperature at which ash softening does not occur.

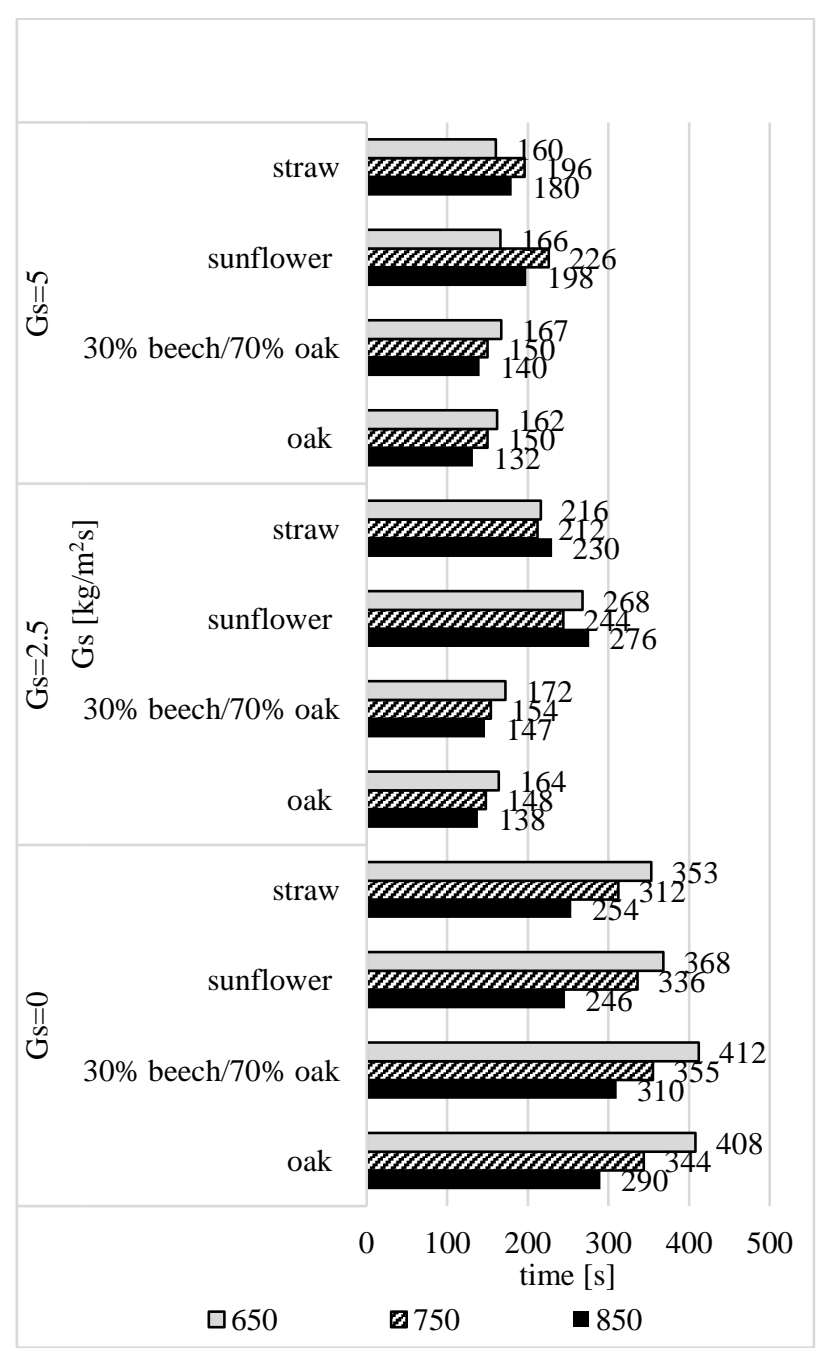

Fig. 2. Comparison of pellets combustion time combusted at different conditions in a circulating fluidized bed.

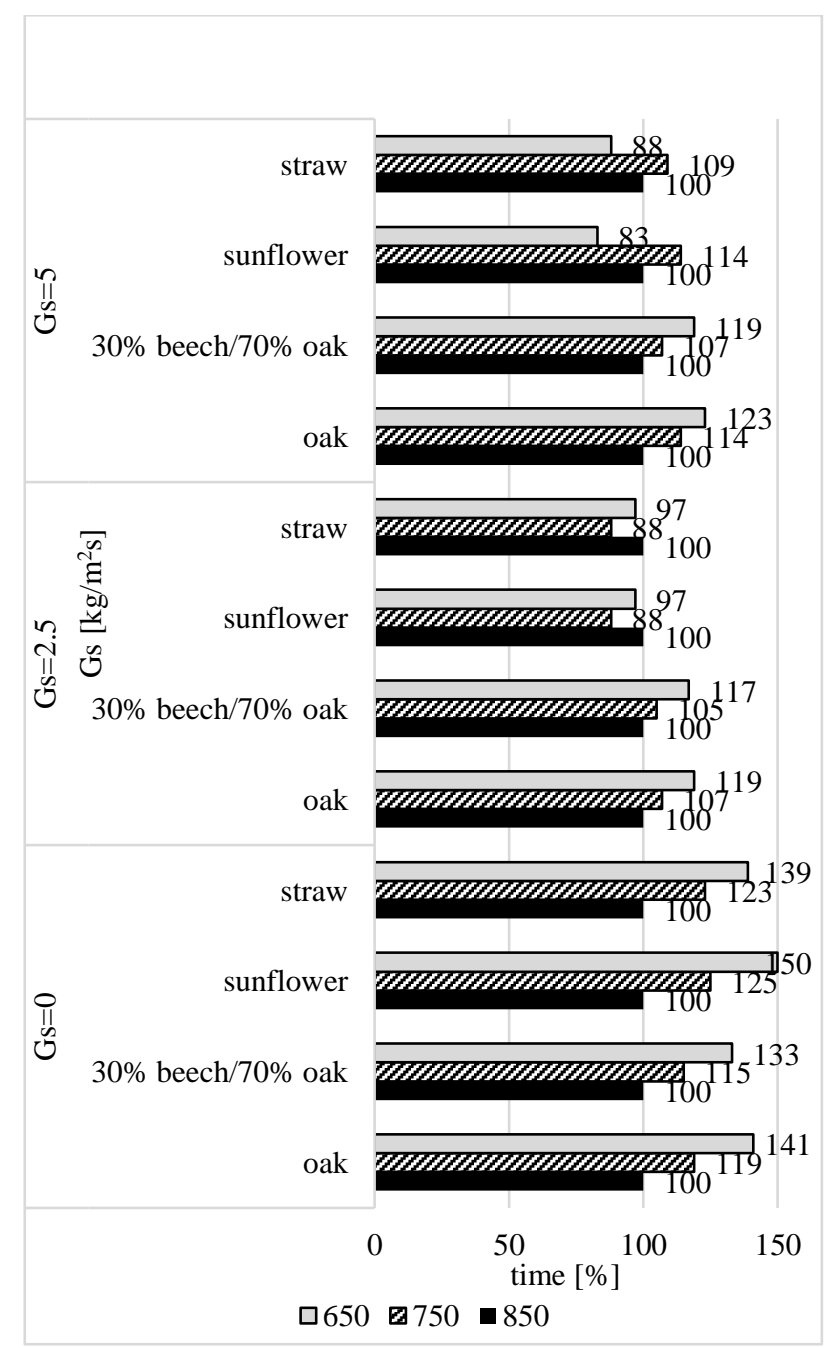

Fig. 3. Percentage comparison of pellets combustion time during reduction of the combustion chamber temperature compared to the reference temperature $\left(850^{\circ} \mathrm{C}\right)$.

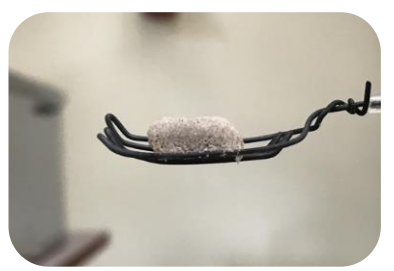

Fig. 4. The residue after combusting sunflower husk pellet at $850^{\circ} \mathrm{C}$, tests were carried out in a stream of inert material at $\mathrm{Gs}=2,5 \mathrm{~kg} / \mathrm{m}^{2} \mathrm{~s}$.

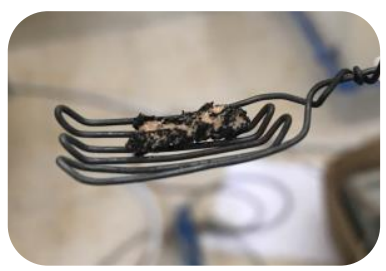

Fig 5. The residue after combusting straw pellet at $850^{\circ} \mathrm{C}$, tests were carried out in a stream of inert material at $\mathrm{Gs}=2,5$ $\mathrm{kg} / \mathrm{m}^{2} \mathrm{~s}$.

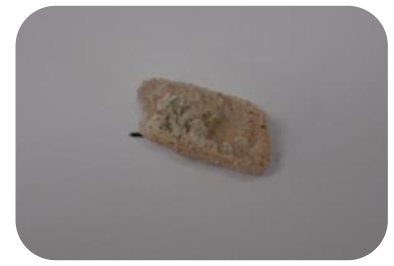

Fig 6. Residue after combusting sunflower husk pellets at $850^{\circ} \mathrm{C}$ and $\mathrm{Gs}=5 \mathrm{~kg} / \mathrm{m}^{2} \mathrm{~s}$. 
Figure 7. shows a comparison of pellet combustion times depending on the stream of inert material combusted at different temperatures ( $\mathrm{Gs}=0$ reference level). The presence of inert material accelerates the mass loss of pellets from oak sawdust. In comparison with combustion without inert material, the combustion time in the stream of material Gs $=2,5 \mathrm{~kg} / \mathrm{m}^{2} \mathrm{~s}$ at any temperature caused a reduction of the combustion time by about $40-50 \%$. On the other hand, a further increase of the inert material stream to $\mathrm{Gs}=5 \mathrm{~kg} / \mathrm{m}^{2} \mathrm{~s}$ to a negligible extent accelerated the combustion process. In the case of combusting sunflower seed pellets compared to combustion without inert material, the combustion time in the $\mathrm{Gs}=2,5 \mathrm{~kg} / \mathrm{m}^{2} \mathrm{~s}$ stream at $650^{\circ} \mathrm{C}$ and $750^{\circ} \mathrm{C}$ has been reduced by approx. $30 \%$, and for $850^{\circ} \mathrm{C}$ combustion time it increased by $12 \%$. Increasing the value of the stream of inert material to $\mathrm{Gs}=5 \mathrm{~kg} / \mathrm{m}^{2} \mathrm{~s}$ resulted in shortening the combustion time at all temperatures. In the case of straw pellets compared to combustion without inert material, the combustion time in the stream of inert material Gs $=2,5$ $\mathrm{kg} / \mathrm{m}^{2} \mathrm{~s}$ at temperatures of $650^{\circ} \mathrm{C}$ and $750^{\circ} \mathrm{C}$ has been reduced by approximately $30-20 \%$, and for temperatures of $850^{\circ} \mathrm{C}$ the combustion time increased by $9 \%$. Increasing the value of the stream of inert material resulted in shortening the combustion time at all temperatures.

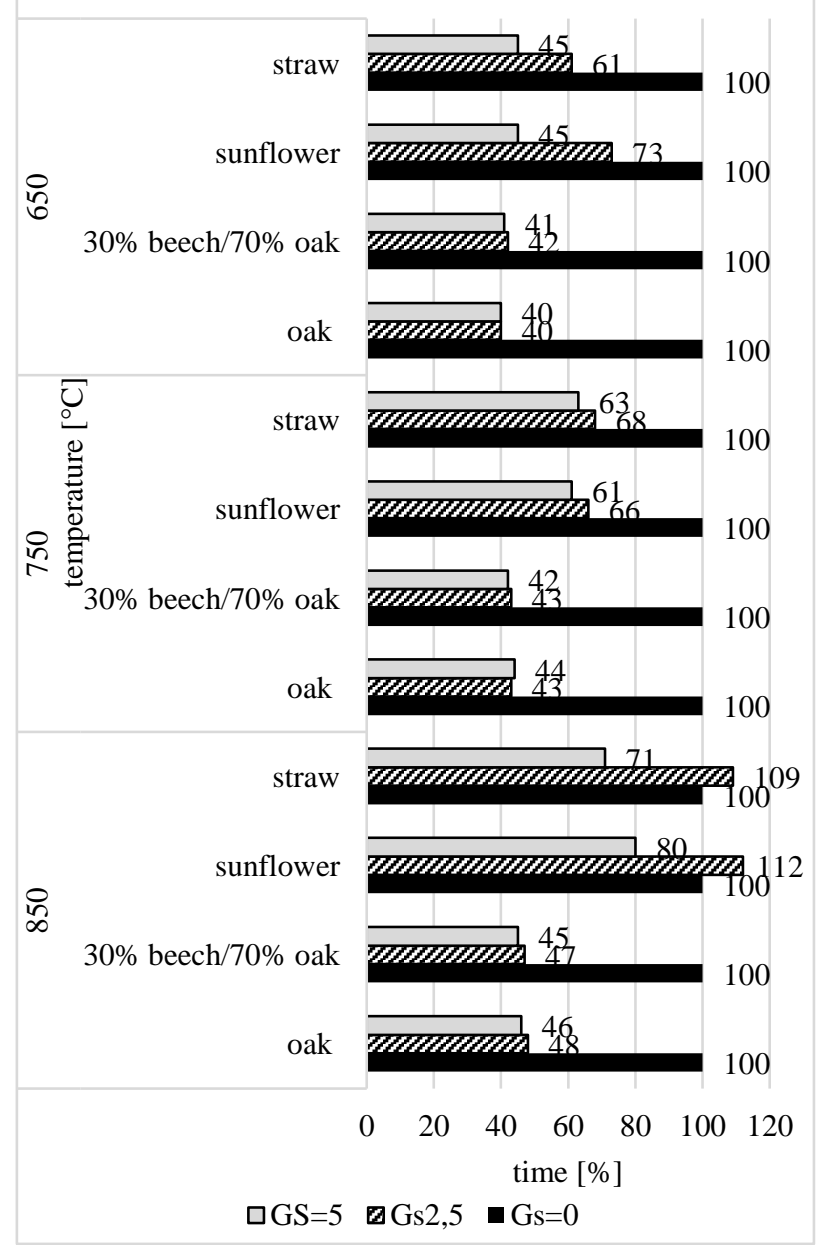

Fig. 7. Comparison of pellet combustion times depending on the value of the Gs material stream combusted at different temperatures ( $\mathrm{Gs}=0$ reference level).

\section{Conclusions}

The analysis carried out as part of the work facilitates the formulation of the following conclusions:

1. Combustion of all types of pellets without inert material and at different temperatures proceeded in a similar and predictable manner described in subjectrelated literature. As the temperature dropped, the combustion time was increased.

2. The appearance of inert material caused very significant differences in terms of time and the combustion mechanism. These differences were mainly observed at $850{ }^{\circ} \mathrm{C}$ for wood and agro-biomass.

3. Combustion of oak sawdust pellets in the stream of inert material $\left(2.5 \mathrm{~kg} / \mathrm{m}^{2} \mathrm{~s}\right.$ and $\left.5 \mathrm{~kg} / \mathrm{m}^{2} \mathrm{~s}\right)$ in each analysed chamber temperature intensifies the process of mass loss of the combusted particles - the amount of air reaching directly to the particle increases as a result of removing ash from its surface of gaseous combustion products through a stream of quartz sand.

4. In the case of sunflower husk and straw pellets, combustion in a stream of inert material in $\mathrm{Gs}=2.5$ $\mathrm{kg} / \mathrm{m}^{2} \mathrm{~s}$ lasts the longest at the highest temperature of the furnace $\left(850{ }^{\circ} \mathrm{C}\right)$. In both cases, the ash softening temperature is exceeded and the quartz sand covers the pellets. Quartz sand coating hinders the flow of the oxidizer to the fuel particle. The combustion time is extended.

5. When the inert material stream was increased in the case of sunflower husk pellets, the coating partially disintegrated, and in the case of straw pellets, the sinter was completely disintegrated.

6. During the combustion of pell ets from oak sawdust, it was noticed that the stronger parameter determining the intensity of the combustion process in comparison with increasing the inert material stream intensity with $\mathrm{Gs}=$ $2.5 \mathrm{~kg} / \mathrm{m}^{2} \mathrm{~s}$ per $\mathrm{Gs}=5 \mathrm{~kg} / \mathrm{m}^{2} \mathrm{~s}$ is increasing the temperature. Increasing the temperature prevailing in the furnace chamber accelerates the mass loss of the pellets combusted (almost 20\%) more than the increase of the inert material stream (only 1-2\%).

7. Experimental research indicates that pellets obtained from various types of biomass (agro and wood) are characterized by a different nature of combustion in fluidic conditions. The ash of different types of biomass contains compounds of alkaline metals whose content affects its softening and melting point.

8. Therefore, it is necessary to operate biomass boilers that are adapted to the properties of biomass combusted. Incorrect boiler temperatures and Gs intensity to the type of fuel supplied may cause an increase in the loss of incomplete combustion and build-up of sediments on the heating surfaces of boilers, as well as disturb the work of circulatory fluidized bed boilers due to the change in the particle distribution of the layer material.

\section{References}

1. Desai, B.G. CO2 emissions-Drivers across time and countries. Curr. Sci., 115, 386-387, (2018). 
2. The International Energy Agency, Global Energy \& CO2 Status Report 2018, The latest trends in energy and emissions in 2018, (2018).

3. Tchapda A.H., Pisupati S.V., A Review of Thermal Co-Conversion of Coal and Biomass/Waste, Energies, 7, 1098-1148, (2014).

4. Greinert A., Mrówczyńska M., Szefner W., The Use of Waste Biomass from the Wood Industry and Municipal Sources for Energy Production, Sustainability, 11, 3083, (2019).

5. UNFCCC, United Nations Framework Convention on Climate Change, (2019)

6. UNSDG, United Nations Sustainable Development Goal report, (2019).

7. Li Y., Rezgui Y., Zhu H., District heating and cooling optimization and enhancement - towards integration of renewables, storage and smart grid. Renew. Sustain. Energy Rev., 72, 281-294, (2017).

8. Pradhana P., Mahajanib S.M., A. Aroraa, Production and utilization of fuel pellets from biomass: A review, Fuel Processing Technology, 181, 215-232, (2018).

9. Chen W.H., Peng J., Bi X.T., A state-of-the-art review of biomass torrefaction, densification and applications, Renew. Sust. Energ. Rev., 44, 847-866, (2015).

10. Singh R., Krishna B.B., Mishra G., Kumar J., Bhaskar T., Strategies for selection of thermochemical processes for the valorisation of biomass, Renew. Energy, 98, 226-237, (2016).

11. Geng A., Yang H., Chen J., Hong Y., Review of carbon storage function of harvested wood products and the potential of wood substitution in greenhouse gas mitigation, Forest Policy Econ., 85, 192-200, (2017).

12. Zhang J., Liu J., Evrendilek F., Xie W., Kuo J., Zhang X., Buyukada M., Kinetics, thermodynamics, gas evolution and empirical optimization of cattle manure combustion in air and oxy-fuel atmospheres, Appl. Therm. Eng., 149, 119-131, (2019).

13. Weiland P., Biogas production: Current state and perspectives. Appl. Microbiol. Biotechnol. 85, 849$860,2010$.

14. Johansson A.-C., Wiinikka H., Sandström L., Marklund M., Öhrman O.G.W., Narvesjö J., Characterization of pyrolysis products produced from different Nordic biomass types in a cyclone pilot plant, Fuel Process. Technol., 146, 9-19, (2016).

15. Mboumboue E., Njomo D., Biomass resources assessment and bioenergy generation for a clean and sustainable development in Cameroon. Biomass Bioenergy, 118, 16-23, (2018).

16. Johansson LS., Leckner B., Gustavsson L., Cooper D., Tullin C., Potter A., Emission characteristics of modern and old-type residential boilers fired with wood logs and wood pellets. Atmos Environ, 38(25):4183-95, (2004).

17. Obernberger I., Biedermann F., Widmann W., Riedl R., Concentrations of inorganic elements in biomass fuels and recovery in the different ash fractions. Biomass Bioenergy, 12(3):211-24. (1997).
18. Wierzbicka A., Lillieblad L., Pagels J., Strand M., Gudmundsson A, Gharibi A, et al. Particle emissions from district heating units operating on three commonly used biofuels. Atmos Environ, 39(1):13950 (2005).

19. Wiinikka H., Gebart R., Boman C., Bostrom D., Ohman M., Influence of fuel ash composition on high temperature aerosol formation in fixed bed combustion of woody biomass pellets. Fuel, 86(12):181-93 (2007).

20. Wiinikka H., Gebart R., Experimental investigations of the influence from different operating conditions on the particle emissions from a small-scale pellets combustor. Biomass Bioenergy, 27(6):645-52, (2004).

21. Brunner T., Obernberger I., Scharler R., Primary measures for low-emission residential wood combustion-Comparison of old with optimised modern systems. Proceedings of 17th European Biomass Conference and Exhibition, Hamburg, Germany, p. 1319-28 (2009).

22. Obernberger I., Brunner T., Barnthaler G., Chemical properties of solid biofuels-significance and impact. Biomass Bioenergy, 30(11):973-82, (2006).

23. Diaz-Ramirez M., Sebastian F., Royo J., Rezeau A., Influencing factors on NOX emission level during grate conversion of three pelletized energy crops. Appl Energy, 115:360-73, (2014).

24. Diaz-Ramirez M., Boman C., Sebastian F., Royo J., Xiong S, Bostrom D., Ash characterization and transformation behavior of the fixed-bed combustion of novel crops: poplar, brassica, and cassava fuels. Energy Fuels, 26(6):3218-29 (2012)

25. Diaz-Ramirez M., Sebastian F., Royo J., Rezeau A., Combustion requirements for conversion of ash-rich novel energy crops in a $250 \mathrm{~kW}$ th multifuel grate fired system. Energy,46(1):636-43, (2012).

26. Diaz-Ramirez M., Frandsen F.J., Glarborg P., Sebastian F., Royo J., Partitioning of K, Cl, S and P during combustion of poplar and brassica energy crops. Fuel, 134:209-19 (2014).

27. Khana A.A.,. de Jong W, Jansens P.J., Spliethoff H., Biomass combustion in fluidized bed boilers: Potential problems and remedies, Fuel Processing Technology, Volume 90, Issue 1, 21-50, (2009).

28. Kosowska-Golachowska M., Wolski K., Gajewski W., Kijo-Kleczkowska A., Musiał T., Środa K., Spalanie biomasy agro i leśnej w cyrkulacyjnej warstwie fluidalnej, Rynek Energii, 3(124), (2016).

29. Jenkins B.M., Baxter L.L., Miles T.R. Jr., Miles T.R., Combustion properties of biomass, Fuel Processing Technology, 54 (1-3) 17-46, (1998).

30. Faaij A.P.C., Biomass combustion, Encyclopedia of Energy 1 175-191, (2004).

31. Demirbas A., Combustion characteristics of different biomass fuels, Progress in Energy and Combustion Science, 30 (2) 219-230, (2004).

32. Demirbas A., Fuel and combustion properties of biowastes, Energy Sources, 27 (5) 451-462, (2005).

33. Pełka P., Analysis of a coal particle mass loss burning in flow of inert material. Combust. Flame, 156, 1604, (2009). 